UDC 621.314

N. Strzelecka1 ${ }^{1}$ Ph.D., T. Sak ${ }^{2}$, R. Strzelecki ${ }^{1}, 2$, Dr.Sc.

${ }^{1}$ Gdynia Maritime University, Morska str 81-87, Gdynia, Poland, 81-226,

2Electrotechnical Institute, Pożaryskiego 28, Warsaw, Poland.

\title{
Novel family of voltage converters with low harmonic distortion using coupled reactors
}

This paper presented a novel approach to the multipulse voltage converters (VC), especially voltage source inverters (VSI) and matric converters (MC) based on several typical identical modules connected in parallel using Inductive Current Splitters/Mergers. Such arrangements resulting in lower voltage distortions at extremely low switching frequency. Proposed new arrangements was validated by simulation. Laboratory models of 18- and 24-pulse 3-level VSI arrangements was also investigated experimentally. Results of simulation and laboratory tests of experimental models are presented in the paper.

References 15, figures 10, tables 1.

Keywords: multipulse voltage converters; matrix converters coupled inductors; inductive current splitte/merger.

\section{Introduction}

Two crucial parameters of currently build high power VC arrangements are the efficiency and the generated waveforms distortion level. Both those parameters rely deeply on switching frequency, but unfortunately the relation is opposite. For high switching frequencies inverters generate less distortions (from power quality and electromagnetic immunity perspective) but they have higher losses. Therefore, one needs to seek for a tradeoff which would allow to achieve satisfactory results.

In [1-4] discuss many different solutions of high power VC. One of the most important aspects of this application is a high efficiency which allows to fully utilize power elements and simplify the cooling system. The following important problems connected with design of high power converters are: the ability for system to extend by its modularity and low EMI distributions level. To achieve a high efficiency at a low switching frequency and to maintain a good power quality multipulse converters were introduced $[5,6]$. These branch of VCs use the parallel operation of identical converter topologies which were typically connected by means of a multi-winding transformer providing the converters with phase shifted voltages. This allows the system generate increased number of voltage vectors compering to less complexed converters. The required rotating voltage vector can be more accurately discretized by the converter when the number of pulses is high (Fig. 1).

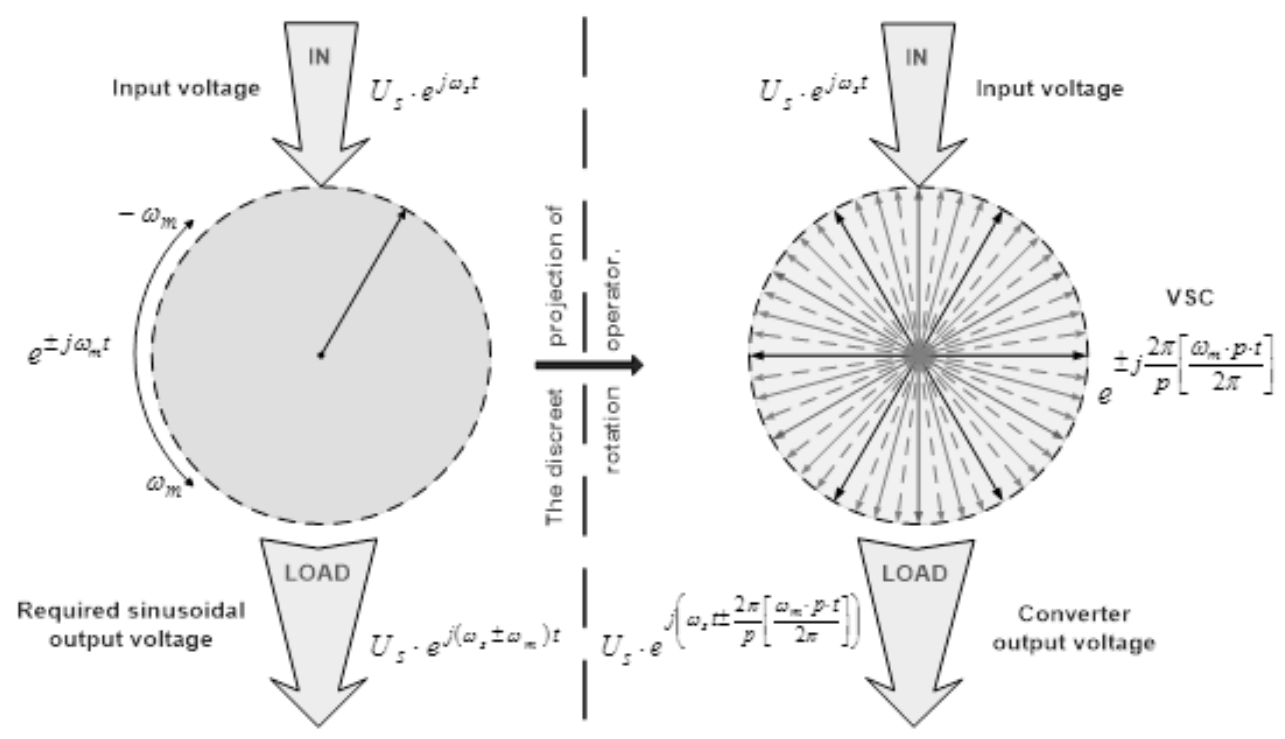

Fig. 1. Principle of operation of multipulse VC's 
The multi-winding transformer has to be rated for the full power of the converter. Thus, is tends to be large and adds significant cost to the converter construction. The use of the coupled inductors instead of the transformer allows to phase shift voltages and to reduce the converter dimensions. The literature provides multiple examples of the coupled inductors use for the multiphase system design. The first group of the converters (which were tested with the use of coupled inductors used for multiphase system design) are the diode based rectifiers. This type of converters benefited from having lower input waveforms distortions [7-10]. Similar advantages are if the proposed coupled inductors structures are applied to DC/AC converters using two level VSI [11].

The paper discusses the method of design and synthesis of a new arrangements of a multipulse VC's, especially multilevel VSI and MC. These VC's are built as modules connected in parallel by means of integrated coupled reactors $[12,13]$. The results of theoretical, simulation and experimental investigations are presented

\section{Proposed multipulse VC}

The overall arrangements of the proposed multi-pulse VC is presented on Fig. 2a. The converter has higher number of the possible voltage vectors which can be applied [14]. The higher number of the VC modules allows to extend the number of voltage vectors which can be applied to the converter output [15]. Further increase of the voltage vector number can be achieved also by paralleling and phase shifting converters. Therefore, a investigated VC's was proposed which are based on multilevel VSI and MC modules and are connected in parallel by means of coupled reactors to achieve high number of output vectors. Two general configurations of the coupled reactors were tested in the interest of this paper. First is current merging connection $\operatorname{CM}(\lambda)$ of single phase inductors presented in Fig. $2 b$ and phase shifting inductors $\operatorname{PS}(\lambda)$ set given in Fig. 2c. The required phase shift of the VC modules can be applied by means of the winding turn ratio recalculation. To calculate required turn ratio for given angle $\lambda$ one should use equation (1a) for $\operatorname{CM}(\lambda)$ element and (1b) for $\operatorname{PS}(\lambda)$ element:

$$
\begin{aligned}
& \text { a) } N_{D} / N_{C}=2 \cos \lambda \text {, } \\
& \text { b) } N_{A} / N_{B}=\frac{\sin \left(2 \pi / p_{n}-\lambda\right)}{\sin \lambda} \text {, } \\
& N_{\Sigma}=N_{A}+N_{B} \text {. }
\end{aligned}
$$

where: $p_{n}-$ is number of pulses of the proposed modular VC.

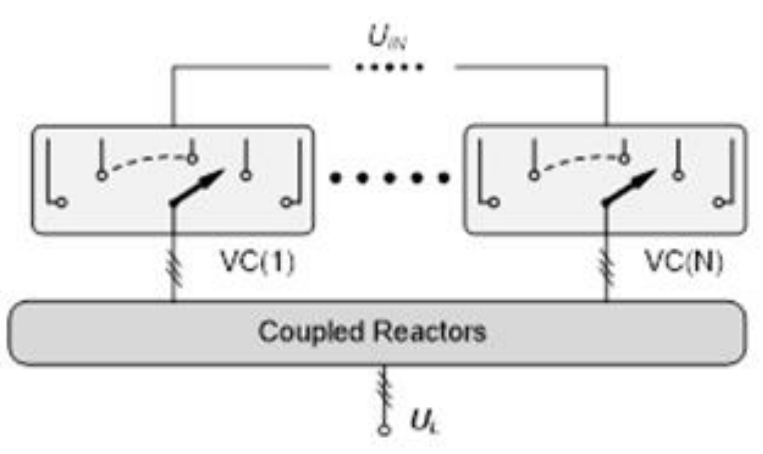

a)
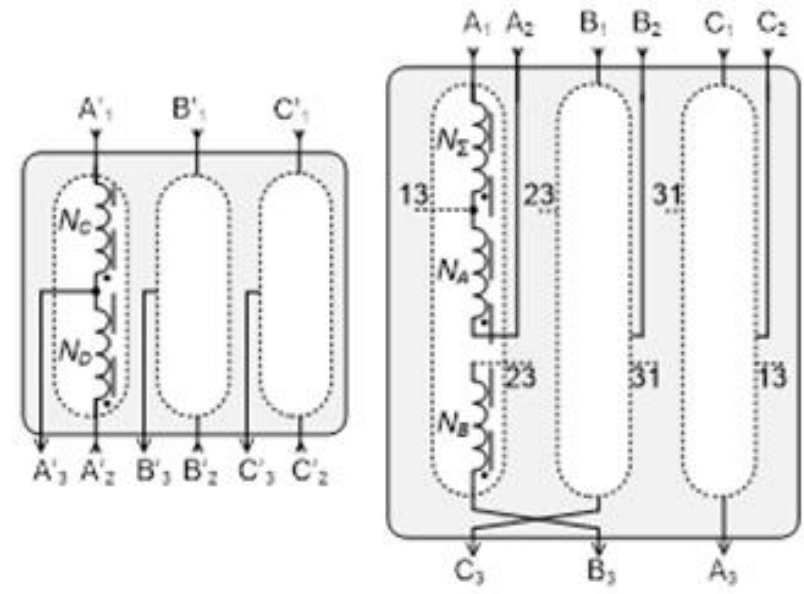

b)

c)

Fig. 2. The overall topology of the proposed multipulse VC (a), and current merger $\operatorname{CM}(\lambda)(b) \mathrm{m}$ and phase shifting $\operatorname{PS}(\lambda)(c)$ coupled reactors

\section{A. Multipulse VSI arrangements}

Fig. 3 presented basic arrangements of the multi-pulse inverters. Used 2- or more levels of the 6-pulse VSI modules are identical. Fig. 4 shows output voltage for different proposed VSI arrange- ments operating at output frequency and switching frequency equal to $50 \mathrm{~Hz}$. The THD voltage coefficient calculated for the tested inverters structures are given in Table 1. One can notice that the increase of voltage levels and pulses can significantly reduce the voltage distortion. These simulation results were obtained for the simplified control 
scheme which was not equipped with the output parameters feedback. Nonetheless, it is possible to arrange full control system structure if e.g. nonline- ar receivers will be supplied from the converter and high power quality is required.

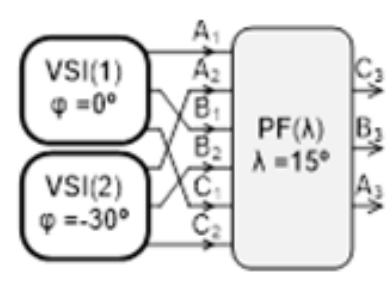

a)

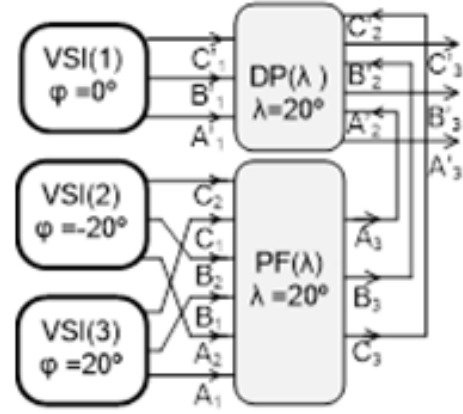

b)

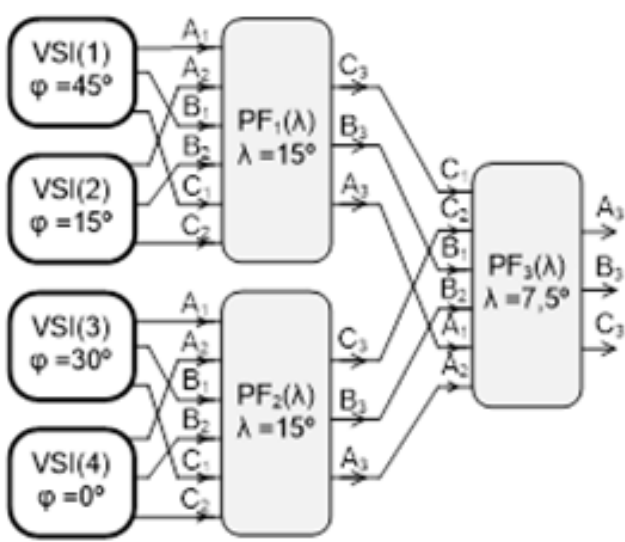

c)

Fig. 3. Structures of connections of 6-pulse VSI modules: 12-pulse VSI arrangement (a), 18-pulse VSI arrangement (b), 24-pulse VSI arrangement (c)
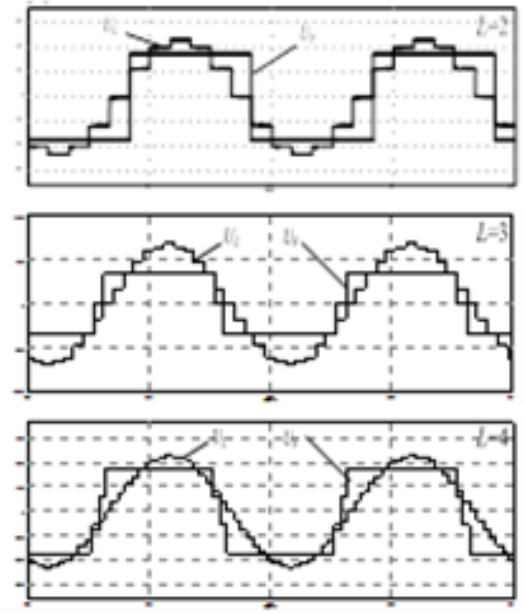

a)
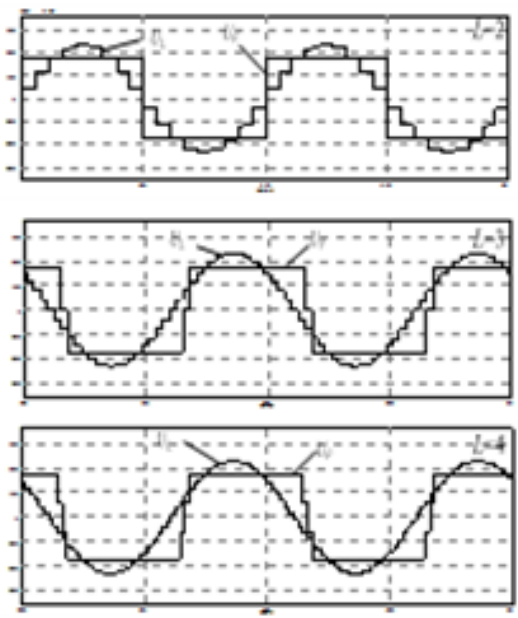

b)
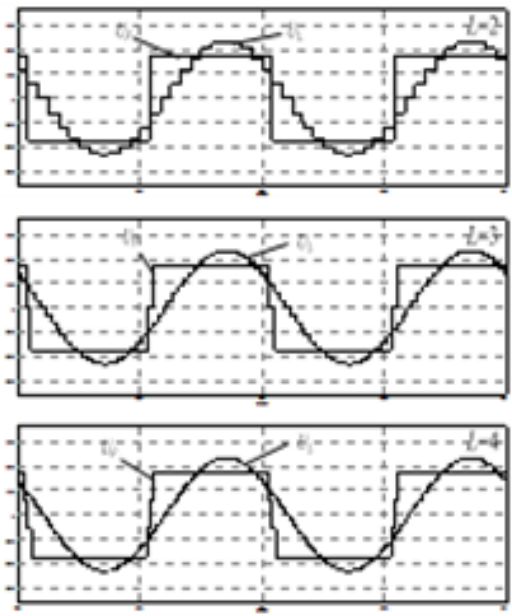

c)

Fig. 4. Output voltage $U_{L}$ and inverter phase voltage $U_{L}$ for proposed multi-pulse VC arrangements operation of 2-, 3- and 4- level VSI modules in: 12-pulse structure (a), 18-pulse structure (b), 24-pulse structure (c)

Table 1. Theoretical value of THD output voltage coefficients of tested the multi-pulse inverter structures

\begin{tabular}{|c|c|c|c|c|}
\hline \multirow{2}{*}{$\begin{array}{c}\text { Number levels (L) } \\
\text { of the VSI modules }\end{array}$} & \multicolumn{4}{|c|}{ Connection type of the VSI modules } \\
\cline { 2 - 5 } & 6-pulse & 12-pulse & 18-pulse & 24-pulse \\
\hline 2 & $31,1 \%$ & $14,7 \%$ & $9,7 \%$ & $7,4 \%$ \\
\hline 3 & $16,9 \%$ & $7,4 \%$ & $4,9 \%$ & $3,7 \%$ \\
\hline 4 & $11,8 \%$ & $5,0 \%$ & $3,3 \%$ & $2,5 \%$ \\
\hline 5 & $9,39 \%$ & $3,83 \%$ & $2,48 \%$ & $1,79 \%$ \\
\hline
\end{tabular}




\section{B. Multipulse MC arrangements}

The proposed multi-pulse MC structures are based on a standard 3-pulse MC modules depicted for example in [2, 3]. Two reactors arrangements from Fig. 2 a possibility to build the wide range of arrangements of the multipulse MC. Three examples of such systems are given in Fig. 5 presenting 6-pulse, 9-pulse and 12-pulse systems accordingly. Detailed 9-pulse MC arrangements presented in Fig. 6 . In this configuration both $\operatorname{CM}(\lambda)$ and $\operatorname{PS}(\lambda)$ reactors structures were used.

The invented multi-pulse MC topologies were validated with the use of PSIM v.10 software simulation models. The nonlinearities of the components were neglected in the simulations. The load was simulated as series connection of a resistor and inductor with $\cos (\varphi)=0,96$. Also, in Fig. 6 voltage and current waveforms fornegative sequence scheme modulated obtained from accordingly typicall 3-pulse and 6-pulse, 9-pulse and 12pulse arrangements of MC were presented. VSA VSB and VSC are input voltage waveforms. ISA is one of input phase currents. On the other hand VLA, VLB, VLC and ILA are the corresponding output parameters. For clarity current waveforms were multiplied by 10 . One might notice that the observed distortion level in the input and output current, but also in the output voltage significantly drops with the number of pulses.

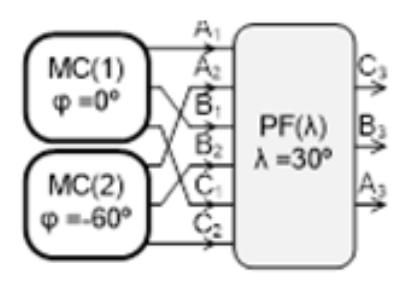

a)

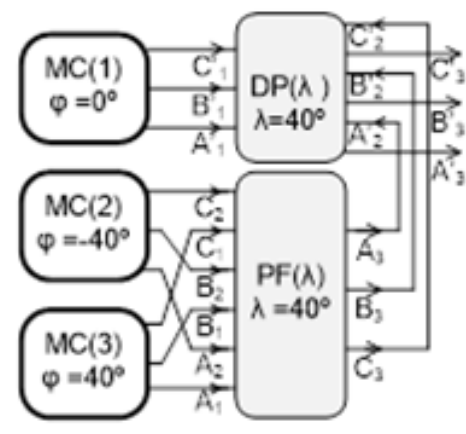

b)

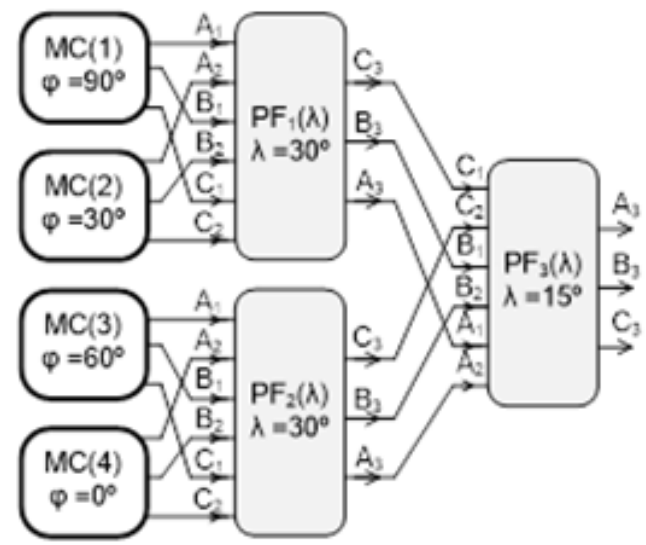

c)

Fig. 5. Structures of connections of 3-pulse MC modules: 6-pulse MC arrangement (a), 9-pulse MC arrangement (b), 12-pulse MC arrangement (c) 

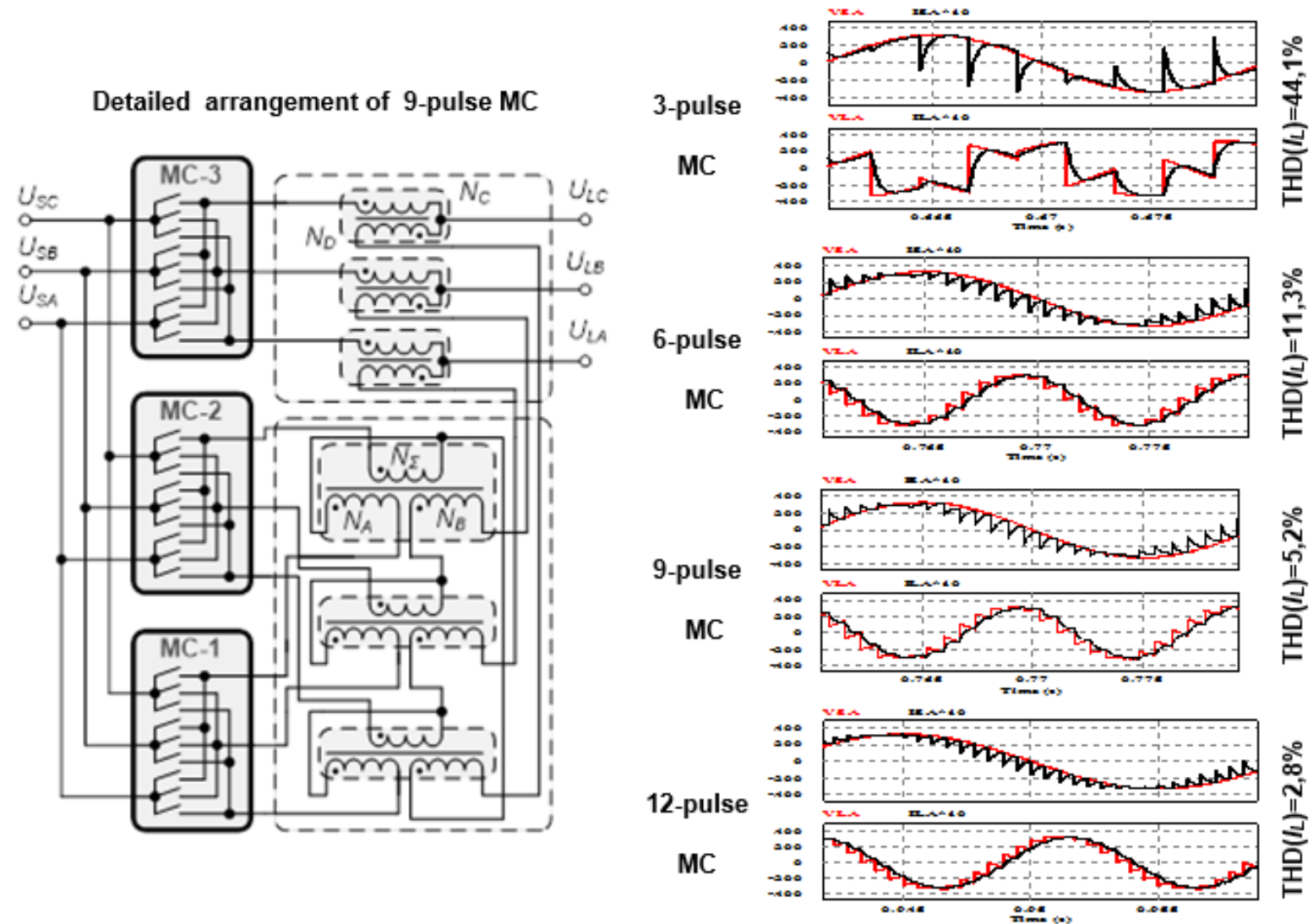

Fig. 6. Example of 9-pulse MC arrangement as well as current and voltage waveforms observed in different multipulse MC arrangements

\section{Experimental results}

Based on analyses it was decided to test 18pulse and 24-pulse NPC VSI arrangements. In the experimental investigated each paralleled VSI module has to be phase shifted by $20^{\circ}$ or $15^{\circ}$ respectively. Fig. 7 presented the laboratory model of 18-pulse NPC VSC arrangement. The model contains three identical NPC VSI, control board, and the set of the coupled inductors. The model is rated for $15 \mathrm{~kW} / 400 \mathrm{~V}$.
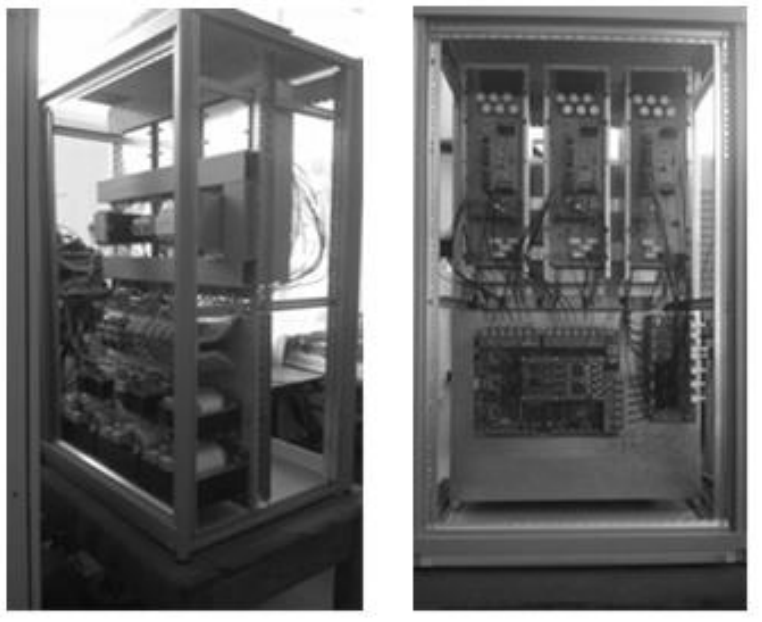

a)

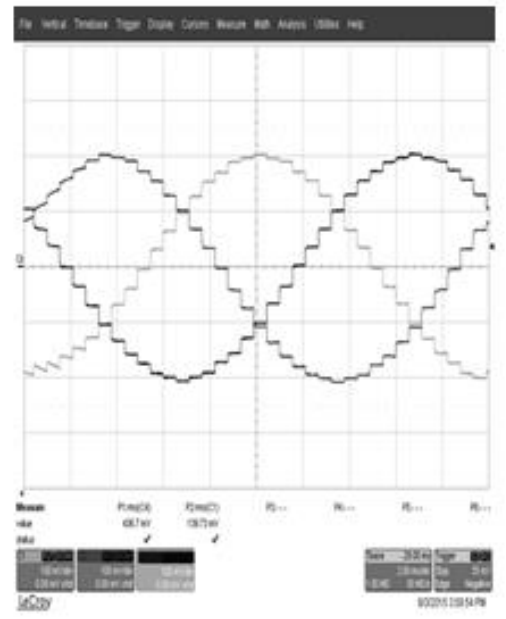

b)

Fig. 7. View of laboratory setup of the 15kW 18-pulse NPC VSI model (a) and output phase current in the case of symmetrical $\mathbf{R}$ load (b) 
As a first experiment, the quality of the voltage waveform generation was tested (Fig. 8). It can be seen that the THD measured has the value below $5 \%$ in the wide range of the output load. The extremely low switching frequency used in the proposed converter allowed to achieve high efficiency of the energy conversion. The efficiency curve as the function of output power is presented also in Fig. 8. The converter was tested with the use 6-pulse diode rectifier.

Fig. 9a presents the waveforms of output voltage and currents observed during the efficiency test. It can be seen that the converter output voltage is not affected by the highly distorted current. This is observed, in that the equivalent impedance of the converter is low, due to the lack of the standard filter. The low equivalent impedance brings another feature to the device. It can easily supply unbalanced load. Such operation was also tested and proofed that the converter voltage balance is not influenced by the nonsymmetrical load. In addition Fig. 9b presents waveforms obtained while the converter was tested under resistive-inductive load.
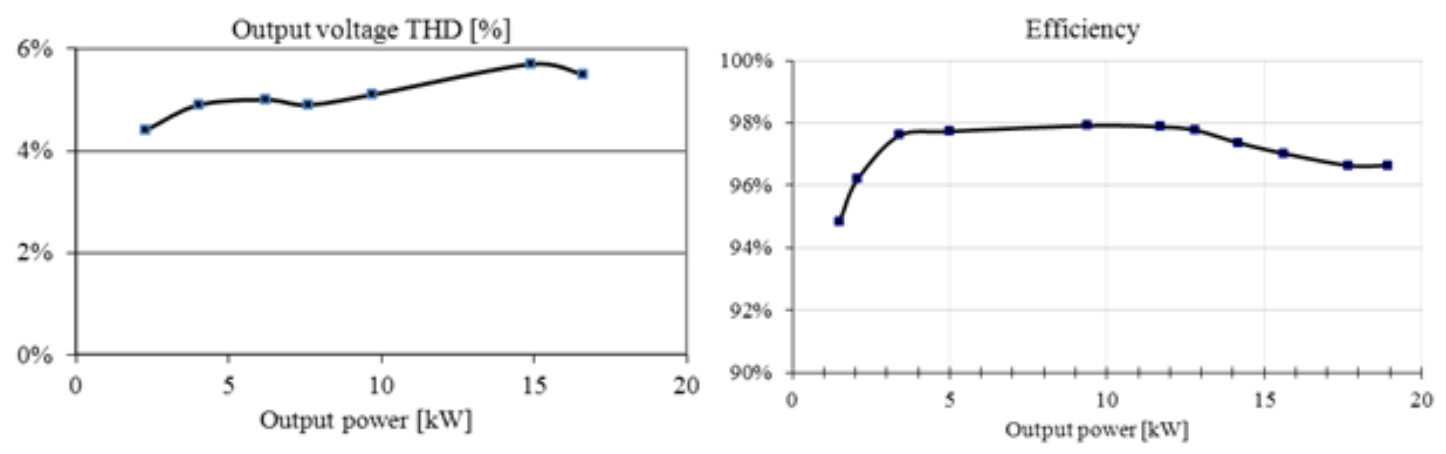

Fig. 8. Output voltage distortion and efficiency of the 18-pulse NPC VSI laboratory model

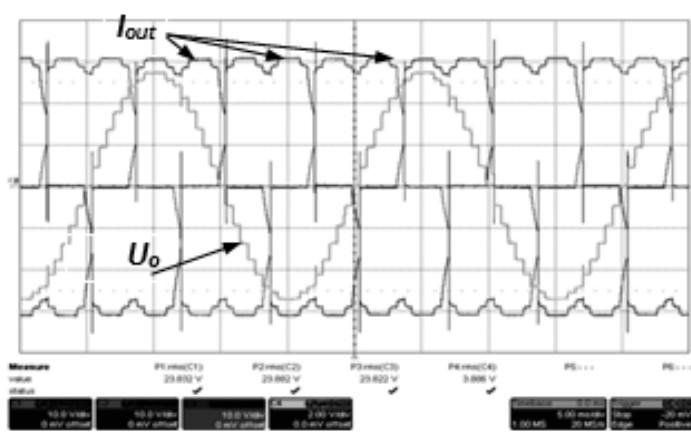

a)

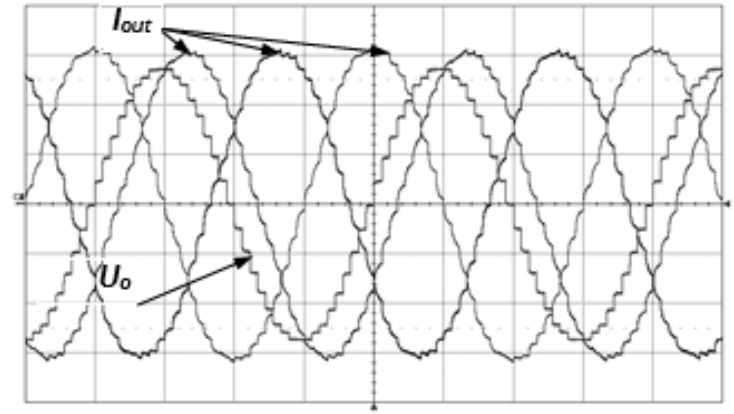

b)

Fig. 9. Typical output voltage and currents during test of 18-pulse NPC VSI model: rectifier (a) and RL (b) load

Additionally, figure 10 shows the voltage and current oscillograms for the above presented 18pulse and newly developed 24-pulse VSI arrangements. As you can see, the increase in the number of pulses significantly improves the quality of the output waveform. It is important at this high accuracy performance coupled reactors. 


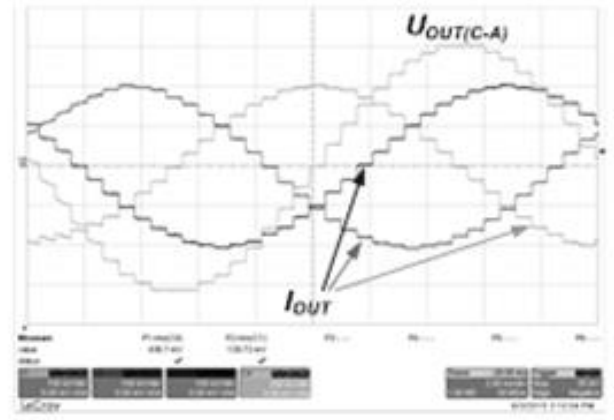

a)

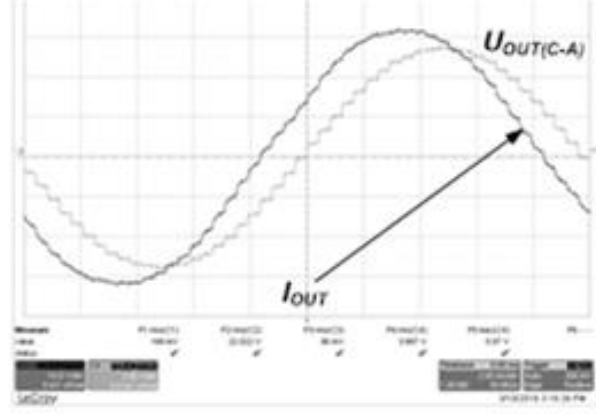

b)

Fig.10. Oscillograms of output voltages and currents for 18-pulse (a) and 24-pulse (a) NPC VSI arrangements

\section{Conclusion}

The result presented in this article suggest that the multi-pulse VC arrangements based on VSI or MC modules connected in parallel by means coupled reactors, is a very promising technology for high power converters. The high power equality and the high efficiency are the advantages of the proposed technology. The proposed VC structures are fulfilling the conditions of the modular scalable technology

\section{References}

1. Soto, D., Green, T. C. (2002). A comparison of high-power converter topologies for the implementation of FACTS controllers. IEEE Trans. on Industrial Electronics, Vol. 49. No. 5. Pp. 1072-1080.

2. Gyugyi, L., Pelly, B. R. (1976). Static power frequency changers: theory, performance, and application. Wiley-Interscience Publication. P. 442.

3. Wheeler, P. W., Rodriguez, J., Clare, J. C., Empringham, L., Weinstein, A. (2002). Matrix converters: a technology review. IEEE Trans. on Industrial Electronics, Vol. 49. No.2. Pp. 276-288.

4. Teodorescu, R., at al. (2002). Multilevel inverter by cascading industrial VSI. IEEE Trans. Ind. Electron., Vol. 49. No. 4. Pp. 832-838

5. Derek, A. Paice. (1966). Power Electronic Converter Harmonics. Multipulse Methods for Clean Power. New York: IEEE PRESS, P.222.

6. Strzelecki, R., Supronowicz, H. (2000). Power factor in AC supply systems and improvements methods. Publishing House of the Warsaw University of Technology, P. 499.

7. Sewan Choi, Enjeti, P. N., Pitel, I. J. (1996). Polyphase transformer arrangements with reduced kVA capacities for harmonic current re- duction in rectifier-type utility interface. IEEE Trans. on Power Electronics. Vol. 11. No. 5. Pp. 680-690.

8. Oguchi, K., Maeda, G., Hoshi, N., Kubata, T. (2001). Coupling rectifier systems with harmonic cancelling reactors. IEEE Industry Applications Magazine. Vol. 7. No.4. Pp. 53-63.

9. Schenk, K., Pietkiewicz, A. (2013). Novel low harmonic rectifier using 12-pulse inductive current splitter/merger. $28^{\text {th }}$ Annual IEEE APEConference. Long Beach. Pp. 978-985,

10. Strzelecki, R., Mysiak, P. (2014). A hybrid, coupled reactors based 18-pulse diode rectifier with active power filter. IEEE Int. Conf. on Intelligent Energy and Power Systems (IEPS). Kiev. Pp. 94-101.

11. Pietkiewicz, A., Biner, H. P. (2012). Novel low harmonic three-phase 12-pulse inverter," Int. SPEEDAM. Sorento. Pp. 837-842.

12. Strzelecki, R., Sak, T., Strzelecka. N. (2015). Sposób i układ do przekształcania energii elektrycznej z wykorzystaniem falowników wielopoziomowych połączonych równolegle. Patent P_414956. Poland.

13. Strzelecki, R., Sak, T., Strzelecka. N. (2015). Układ do przekształcania energii elektrycznej z wykorzystaniem przekształtników matrycowych połączonych równolegle. Patent P_4141957. Poland.

14. Peng, F. Z., Wei Qian, Dong Cao. (2010). Recent advances in multilevel converter/inverter topologies and applications. Int.Power Electronics Conference (IPEC). Sapporo. Pp. 492501.

15. Ahmed, I., Borghate, V.B. (2014). Simplified space vector modulation technique for sevenlevel cascaded $\mathrm{H}$-bridge inverter. IET Power Electronics. Vol. 7. No. 3. Pp. 604-613.

Поступила в редакцию 29 июля 2016 г. 
УДК 621.314

Н. Стжелецки ${ }^{1}$, канд. техн. наук, Т. Сак², Р. Стжелецки ${ }^{1,2}$, д.-р. техн. наук

1Морской университет Гдыни, ул. Морская 81-87, Гдыня, Польша, 81-226.

2Электротехнический институт, Пожарского 28, Варшава, Польша.

\title{
Новое семейство преобразователей напряжения с низким уровнем гармонических искажений с использованием соединенных индуктивностей
}

В данной статье представлен новый подход к многоимпульсным преобразователям напряжения, в том числе инверторам напряжения и матричным преобразователям на основе нескольких типовых идентичных модулей, соединенных параллельно с использованием Inductive Current Splitters / Mergers. Такие механизмы приводит к снижению напряжения искажения при низкой частоте переключения. Предлагаемые новые механизмы были подтверждены с помощью моделирования. Лабораторные модели 18- и 24-импульсных 3-уровневый преобразователей напряжения были также исследованы экспериментально. Результаты моделирования и лабораторных испытаний экспериментальных моделей представлены в работе. Библ. 15, рис. 10, табл. 1.

Ключевые слова: многоипульсные преобразователи напряжения; матричные преобразователи; катушки индуктивности; гармонические искажения.

УДК 621.314

Н. Стжелецкі ${ }^{1}$, канд. техн. наук, Т. Сак², Р. Стжедецкі ${ }^{1,2}$, д.-р., техн. наук 1Морський університет Гдині, вул. Морська 81-87, Гдиня, Польша, 81-226, Електротехнічний інститут, Пожарського 28, Варшава, Польша.

\section{Нове сімейство перетворювачів напруги з низьким рівнем гармонійних спотворень з використанням з'єднаних індуктивностей}

\begin{abstract}
У даній статті представлений новий підхід до багатоімпульсних перетворювачів напруги, зокрема інверторів напруги і матричних перетворювачів на основі кількох типових ідентичних модулів, з'єднаних паралельно з використанням Inductive Current Splitters/Mergers. Такі механізми призводить до зниження напруаи спотворення при низькій частоті перемикання. Пропоновані нові механізми була підтверджені за допомогою моделювання. Лабораторні моделі 18- $і$ 24імпульсних 3-рівневих перетворювачів напруги були також досліджені експериментально. Результати моделювання і лабораторних випробувань експериментальних моделей представлені в роботі. Бібл. 15, рис. 10, табл. 1.
\end{abstract}

Ключові слова: багатоіпульсні перетворювачі напруги; матричні перетворювачі; котушки індуктивності; гармонічні спотворення.

\section{Список використаних джерел}

1. Ahmed, I., Borghate, V.B. Simplified space vector modulation technique for seven-level cascaded Hbridge inverter. IET Power Electronics. Vol. 7. No. 3. - 2014. Pp. 604-613.

2. Derek A. Paice. Power Electronic Converter Harmonics. Multipulse Methods for Clean Power. New York: IEEE PRESS, - 1966. P.222.

3. Gyugyi L., Pelly B.R. Static power frequency changers: theory, performance, and application. WileyInterscience Publication. - 1976. P. 442.

4. Oguchi, K., Maeda, G., Hoshi, N., Kubata, T. Coupling rectifier systems with harmonic cancelling reactors. IEEE Industry Applications Magazine. Vol. 7. No.4. - 2001. Pp. 53-63.

5. Peng, F.Z., Wei Qian, Dong Cao. Recent advances in multilevel converter/inverter topologies and applications. Int.Power Electronics Conference (IPEC). Sapporo. - 2010. Pp. 492-501. 
6. Pietkiewicz, A., Biner, H. P. Novel low harmonic three-phase 12-pulse inverter," Int. SPEEDAM. Sorento. - 2012. Pp. 837-842.

7. Schenk, K., Pietkiewicz, A. Novel low harmonic rectifier using 12-pulse inductive current splitter/merger. 28th Annual IEEE APEConference. Long Beach. - 2013. Pp. 978-985.

8. Sewan Choi, Enjeti, P.N., Pitel, I.J. Polyphase transformer arrangements with reduced kVA capacities for harmonic current reduction in rectifier-type utility interface. IEEE Trans. on Power Electronics. Vol. 11. No. 5.- 1996. Pp. 680-690.

9. Soto, D., Green, T.C. A comparison of high-power converter topologies for the implementation of FACTS controllers. IEEE Trans. on Industrial Electronics, Vol. 49. No. 5.- 2002. Pp. 1072-1080.

10. Strzelecki, R., Mysiak, P. A hybrid, coupled reactors based 18-pulse diode rectifier with active power filter. IEEE Int. Conf. on Intelligent Energy and Power Systems (IEPS). Kiev. - 2014. Pp. 94-101.

11. Strzelecki, R., Sak, T., Strzelecka. N. Sposób i układ do przekształcania energii elektrycznej z wykorzystaniem falowników wielopoziomowych połączonych równolegle. Patent P_414956. Poland.- 2015.

12. Strzelecki, R., Sak, T., Strzelecka. N. Układ do przekształcania energii elektrycznej z wykorzystaniem przekształtników matrycowych połączonych równolegle. Patent P_4141957. Poland. -2015.

13. Strzelecki, R., Supronowicz, H. Power factor in AC supply systems and improvements methods. Publishing House of the Warsaw University of Technology, - 2002. P. 499.

14. Teodorescu R., at al. Multilevel inverter by cascading industrial VSI. IEEE Trans. Ind. Electron., Vol. 49. No. 4. - 2002. Pp. 832-838.

15. Wheeler, P.W., Rodriguez, J., Clare, J.C., Empringham, L., Weinstein, A. Matrix converters: a technology review. IEEE Trans. on Industrial Electronics, Vol. 49. No .2. - 2002. Pp. 276-288. 